\title{
Medical editors urged to accept ethical code
}

Jim Giles, London

Editors of medical journals should be as accountable for their actions as the authors they publish, according to a group of editors that has drawn up a code of conduct for scientific publishing.

"Like everybody else, we are much more interested in other people's accountability than we are in our own," explains Richard Smith, editor of the British Medical Journal $(B M J)$, who helped to draft the new code. "Editors are perhaps some of the most unaccountable people in the world."

The London-based Committee on Publication Ethics (COPE), a body established in 1997 to help editors discuss ethical issues, published a draft of the code on its website on 27 February. It says that a final version will be ready in the next few months, and wants all editors of medical journals, including its 180 or so members, to sign up to the code and agree to be bound by the associated disciplinary procedures.

Many of the code's requirements, such as the need to establish systems for managing conflicts of interest among editors and other journal staff, are uncon-

tentious. Other parts call for more significant changes in editorial behaviour. When a journal suspects that the author of a paper has behaved unethically, for example, the code states that the editor must ensure that a relevant body, such as the author's employer, will carry out a proper investigation.

As COPE's annual report for 2003 reveals, editors face that situation quite frequently. One submitted paper, it says, revealed that to set up a control group for a study, blood samples were taken from healthy babies - a painful procedure that the paper's authors later admitted would never receive ethical approval. Another described how a patient with a serious disease was treated with a complementary therapy based on a plant extract, when a standard and effective conventional treatment was available.

Having received unsatisfactory explanations from the authors, editors from both journals concerned are contacting regulatory authorities. "We used to just reject cases like this, but things have changed since COPE was established," says Smith, who is vice-chair of COPE's governing council. Smith believes that having access to papers that are not in the public domain allows journal editors to act as "privileged whistleblowers".

The code also confronts bad practice by editors themselves. COPE's 2003 report details several possible cases of this, including allegations that a journal made authors add references to other papers it had published in order to boost its impact factor. The editor approached COPE after being sacked for complaining to senior staff about the practice, and the committee is investigating the case.

Another allegation generated lengthy discussion when distributed on an e-mail list run by the World Association of Medical Editors. The case involved an essay that was accepted for publication in October 2001 by a medical journal. Four months later, the author received a letter saying that a backlog of papers had forced the journal to reconsider the threshold for publication, and that the article had been rejected.

The story drew sympathy and anger from list members. After 25 posts, almost all critical, the offending editor came forward. "I cannot tell a lie," Smith wrote, as he admitted that he himself had made the change.

In his defence, Smith argues that his action best served the interests of his readers. The code does not cover the legitimacy of such decisions, but Smith points out that had it been in place, COPE would at least have had a framework within which to consider a complaint from the author.

Philip Campbell, editorin-chief of the Nature titles, says he is currently considering the guidelines. But editors at some publications are uncertain about signing up. Drummond Rennie, deputy editor of the Journal of the American Medical Association, says that complaints about his publication are handled by a board of independent academics. He feels that this committee is already doing a good job of dealing with complaints directed at editors. Rennie adds that the code would be more useful for smaller journals with fewer resources.

But members of COPE will have to go some way to compete with notable historical episodes of editorial wrongdoing. The committee's report cites the example of the late Cyril Burt, who founded the British Journal of Statistical Psychology in 1947 and was one of the pioneers of using twins to study the environmental and genetic origins of intelligence.

Some of Burt's studies have been discredited because of the apparent fabrication of data, and the COPE report points out that his editorial conduct, which included adding references to his own work to papers published by other authors, was not much better. "His coup de grâce," says the report, "came when he published a letter that he had written under a pseudonym, along with a response he also wrote himself under another pseudonym, so that he could attack a colleague."

www.publicationethics.org.uk 